\title{
The Latin American social agenda in the year 2000
}

\section{Rolando Franco}

Director of the ECLAC

Social Development Division

rfranco@eclac.cl

Pedro Sáinz

Director of the ECLAC

Statistics and Economic

Projections Division

psainz@eclac.cl
Now that the 1990s have ended and a new millennium is dawning, the low rate of economic growth, the region's vulnerability to international financial instability and the limited progress made in terms of equity oblige us to reflect on the social agenda for the future. An important role in that agenda will continue to be played by the efforts to overcome poverty and indigence, conditioned to a large extent by the region's capacity for economic change and its dynamism in creating large numbers of jobs of higher quality in terms of productivity and income. At the same time, in view of the heavy burden of unfulfilled social needs that still persists, it is essential that social programmes should use their resources efficiently and -in order to be prepared for possible crisessafety nets should be established to cope with periods of recession. Those programmes must attach great importance to the creation of human capital, taking care to improve the present unsatisfactory distribution of education between the social strata, which is one of the symbols of Latin America's social shortcomings. Education alone, however, is not enough to overcome the lack of equity, improve income distribution and generate a situation of social mobility which will give sons and daughters better opportunities for material well-being and social status than their parents had. Economic change should take advantage of the better levels of education achieved by creating more jobs of higher productivity, for which purpose it will be necessary to increase the present investment coefficients and the procurement and dissemination of technical progress. A better mix of labour, capital and technical progress will lay the foundations for more inclusive and equalitarian societies. 


\section{Introduction}

The vulnerability of most of the countries of the region to international financial instability, the low rates of economic growth, the limited progress made in terms of equity, and the dissatisfaction observable in public opinion have modified the coordinates of the economic and social debate under way in the region, bringing into question some of the principles on which the prevailing development models are based.

On the one hand, it has been proposed that changes should be made in the international financial architecture (ECLAC, 1998) in order to favour sustainable stability and facilitate the taking of timely decisions to forestall or handle crises (ECLAC, 1999a).

In the international debate, great concern has also been expressed for equity, ${ }^{1}$ although it is also stressed that macroeconomic discipline should be maintained (Camdessus, 1996). It has been asserted that development is something more than adjustment, and that so far we have concentrated too much on economic aspects, without taking due account of the social, political, environmental and cultural aspects of society. We should therefore go beyond financial stabilization and address the problem of long-term growth with equity, which is the basis for human prosperity and progress (Wolfenson, 1998).

At the same time, in Europe a debate has arisen about the degree of inequality which is "tolerable" in those societies and the viable alternatives for developing (or maintaining) protection of the most vulnerable sectors (Giddens, 1998). In that connection, the idea of pursuing these objectives through a "Third Way" more

\footnotetext{
${ }^{1}$ Good social policies are called for, because without them globalization and democracy would lose legitimacy. It is recommended that social safety nets should be established, that agrarian reform should be carried forward, that equality of opportunities should be promoted, and that extreme inequalities of income distribution should be reduced through fair transfers of income from the richest sectors to the neediest, from the healthy to the sick, and from those who have jobs to those who have not (Camdessus, 1996, p. 35).
}

or less midway between the traditional options has gained considerable currency, at least in the media. ${ }^{2}$

In Latin America, for its part, the optimism of the early 1990s has been lost. The successive crises led to an economic growth rate below that of other eras. It may be recalled that in the early 1970s the regional product was growing at around $6 \%$ per year, but towards the end of that decade the growth rate had gone down to $1.5 \%$, and it fell to zero with the crisis of the $1980 \mathrm{~s}$. In the first half of the 1990s there was an encouraging recovery, with growth reaching $3 \%$ and attaining a peak of $5.3 \%$ in 1997 , only to fall back in 1998 to $2.5 \%$. In 1999 growth was negative in most of South America, and it recovered only feebly in 2000. Another point of concern in the region is that this slow growth is not generating sufficient good-quality jobs to give employment to those entering the labour force, especially young people and women. This has been reflected in signs of dissatisfaction among the public, loss of interest for political activity in some cases, and criticisms of the way the political parties and governments operate.

In view of such a legacy of the 1990s, it is worth reflecting about the issues that form part of the social agenda in Latin America and will mark the first years of the new century.

\footnotetext{
${ }^{2}$ Various different approaches have been proposed. A broad group of world political leaders seem to coincide with the supporters of the "Third Way", who seek to combine the social-democratic contributions of the period dubbed "the glorious thirties" with the recognized advantages of the market. There are social democrats who are reluctant to support these changes, however, while some analysts, who consider that "social-democratic ideas do not make sense [at present], because they correspond to the return to power of trade unionism, which is at present on the retreat all over the world" but at the same time feel that the new "social liberalism" represents a centre-right alliance between the State and economic forces, propose instead a " $2 \frac{1}{2}$ " alternative in which the State gives greater weight to social pressures (Touraine, 1998). Other sectors also seem disposed to adopt renewed perspectives, as in the United States, with the idea of "compassionate conservatism" (Olasky, 2000), which was adopted by one of the presidential candidates (one of whom wrote the foreword to the book in question), and in the region itself, with the efforts to construct a "reformist centre". Mention should also be made of some points of coincidence which go beyond political traditions (Blair and Aznar, 2000).
} 


\section{II}

\section{The present social situation}

\section{Poverty and indigence}

According to measurements made by ECLAC, the incidence of poverty in Latin America went down from $41 \%$ to $36 \%$ between 1990 and 1997, thus returning to a level similar to that prevailing before the debt crisis. Indigence evolved in a similar manner, going down from $18 \%$ to $15 \%$ over the same period (ECLAC, 1999b). The 1998-1999 crisis increased the proportion of poor people in some countries and caused a slackening in the favourable tendency previously observed in some others, so that the decade closed with nearly $38 \%$ of households under the poverty line and $16 \%$ in a state of indigence (ECLAC, 2000).

As a result, whereas the reduction in poverty in the first part of the 1990s made it possible to stabilize the number of poor persons, the impact of the subsequent crisis caused the number of poor to rise to nearly 220 million and the number of indigent persons to increase from 93.4 million to nearly 100 million (ECLAC, 2000).

Two conclusions may be drawn from what happened in the region in these years. Economic growth can be said to have had a positive impact on the reduction of poverty, although the degree of reduction depends on the particular growth profile, while the regressive impact of the episodes of recession on poverty reduction is also clear: one year of recession caused the loss of between 50 and 100\% of the advances made in this respect in four or five years of growth.

\section{Employment and unemployment}

Towards the end of the 1990s, not only did growth slacken but there were also increases in open unemployment and in the percentage of non-permanent wage earners and the number of workers without employment contracts and without social security (ECLAC, 2000, pp. 49-53 and 95-102).

In 1999 the average rate of open unemployment in the region (8.7\%) was the highest in the decade, even though the rate of participation in the labour force had gone down from $58.5 \%$ to $57.9 \%$. Two different situations should be distinguished in this respect, however: while Mexico and some Central American and Caribbean countries registered appreciable economic buoyancy and a decline in unemployment, the latter indicator increased in the South American countries, which had problems of economic stagnation. The phenomenon was particularly notable in Chile, where the unemployment rate rose from $6.4 \%$ in 1996 to $9.8 \%$ in 1999 (ECLAC, 2000, p. 95) and continued to rise in the year 2000 , reaching $10.6 \%$. A similar trend was observed in Argentina, although it was not so marked, since although the product went down by $3 \%$ unemployment only increased from $12.9 \%$ to $14.3 \%$.

There were also significant changes in the organization of work, which was marked by an increase in precarious employment. Labour deregulation was further increased through the reduction of labour costs, more short-term hiring (temporary, seasonal or parttime work), the broadening of grounds for the termination of contracts, the reduction of severance payments, and the restriction of the right to strike, all with the aim of maintaining or increasing economic competitiveness at the international level.

There has thus been an increase in non-permanent employment, although to very varied levels ranging in 1997 from $9.5 \%$ in Costa Rica to $45.1 \%$ in Ecuador, with extreme rates of increase in Colombia, where it rose from $6.6 \%$ in 1980 to $20.0 \%$ in 1997 . This type of temporary employment is most common in microenterprises and among persons under 30, women and people of low educational level (Martínez and Tokman, cited in ECLAC, 2000, p. 99).

There was also an increase in the number and proportion of those with jobs but without any employment contract. In 1996 the proportion of wageearners in this situation ranged from $65 \%$ to $22 \%$, depending on the country. Such precarious employment was naturally linked with lower wages and greater vulnerability and poverty.

A substantial proportion of workers did not have social security or health protection. There are notable differences between countries in this respect: over $60 \%$ of workers lack such protection in Bolivia and Paraguay, whereas almost all workers are covered in Uruguay (ECLAC, 2000, p. 101).

THE LATIN AMERICAN SOCIAL AGENDA IN THE YEAR 2000 • ROLANDO FRANCO AND PEDRO SAINZ 


\section{Income distribution}

During the 1980s, governments centered their attention on economic growth and the relief of poverty, assuming that for this purpose it was sufficient to recover the macroeconomic balances, end inflation, do away with the presence of the State in certain areas and expand the spaces open for the private sector. Many of those who advocated these policies thought that in the long term the trickle-down effect would put an end to poverty. Improvement of income distribution was not an objective in itself because it was believed that measures to promote this could affect both economic growth and the possibility of reducing poverty through such growth.

Today, income distribution has gained political importance once more, both because economic growth does not generally seem to have led to better distribution and because the economic debate has taken up the question of income distribution once again, relating it with three important issues.

A first line of analysis has taken up once again the theory that more equalitarian income distribution promotes economic growth, in contrast with the argument that -at least in the first phases of the development process-income should be concentrated in certain groups that have the capacity to save and invest. Doubts have also been expressed as to whether the higher-income groups in the region have this capacity, in view of the propensity to consume that they usually show (ILPES, 1999, pp. 15-19).

A relation has also been traced between income distribution and poverty. The argument in this respect, which is of a mechanical nature, holds that there is now "unnecessary" poverty in Latin America (Berry, 1997), because if the income distribution of the early 1980s had been maintained, the increase in poverty as a result of the crisis would have been 50\% smaller (Londoño and Szekely, 1997).

Finally, it is held that the reduction of inequalities increases the stability of democratic political systems, whereas concentration gives rise to greater risks, due to the reaction of losing groups seeking to improve their inferior position.

Income distribution in Latin America in the 1990s may be analysed through the following indicators:

i) the percentage of households with an income below the average for the society in question rose from $67 \%$ to $75 \%$ between 1970 and 1990 and remained at that level throughout the 1990s. This indicates that the evolution of average income does not adequately reflect what is happening in threequarters of the Latin American population;

ii) the Gini coefficient indicates that between 1990 and 1997 inequality increased in seven countries and went down in only four (ECLAC, 1999b). It may be recalled that Latin America is the region with the worst income distribution in the world, although it should be noted that it is a heterogeneous set of nations which are very different from each other in this respect, with Brazil and Uruguay at the two extremes (ECLAC, 1998, pp. 216-217, table 23);

iii) the ratio between the income of the richest $10 \%$ of the population and the poorest $40 \%$ increased between 1990 and 1997 in seven countries and went down in only four (ECLAC, 1999b, pp. 64 and 66).

It may be concluded, then, that even in the best of cases the form of economic growth that has prevailed in the region in recent years has done nothing to reduce the inequalities that have traditionally been characteristic of the area. However, "these problems are not a result of the present development model, since they were also typical of the preceding and even earlier models. They thus reflect fundamental problems of the economic and social structure which we should not try to conceal" (Ocampo, 2000, p. 125).

This tendency towards inequality does not seem to be peculiar to Latin America. It is also found even in the developed world, albeit with other levels of concentration. In the United States, for example, several analysts have noted that information technologies increase the employment and income opportunities for "symbolic analysts", which is the term used to denote highly-qualified workers engaged in the production of non-material knowledge-intensive goods (Reich, 1993). In contrast, assembly-line workers are affected by the increasing requirement that they should have qualifications in informatics and the fact that companies are transferring their routine production processes to other countries (Thurow, 1992). Likewise, in the European Community notable differences have been observed between the incomes of the better-off sectors of the population, which are increasing significantly, and the employment possibilities, type of employment and wages of the bottom $40 \%$ of the population (Dahrendorf, 1996, p. 44).

These characteristics of the world economic system, which are due in part to the incorporation of new technologies, are compounded in Latin America by specific factors which explain the concentration of 
income distribution and make it less easy to modify in the short term.

ECLAC (1998) identifies four factors which are particularly important in this connection:

i) Wealth: The distribution of wealth in Latin America is even more concentrated than that of total income. On average, income from wealth stands at percentile 85 (ECLAC, 1998, figure 4), which means that $85 \%$ of the Latin American population have less access to wealth than the average level for society as a whole.

ii) Demography: Lower-income households have more members (five or more persons on average) than households in the upper income levels.

iii) Employment: Employment density - that is to say, the number of employed persons in relation to the total number of persons in the household- is particularly important for explaining what is happening with regard to income distribution. In some countries, the upper strata register values of this indicator which are twice those of the lower strata. In view of the importance of labour income in total household income, this disparity explains much of the high degree of income concentration. The distance between those in the first income distribution decile and those in the bottom $40 \%$ is also increased by the growing disparity between the wages paid in modern occupations and those paid in low-productivity jobs.

iv) Education: Income distribution is also conditioned by education. Although the amount of schooling has increased over the last 25 or 30 years, so that the new generations have an average of three more years' schooling than their parents, there is still a high degree of concentration of educational capital.

\section{Social expenditure: a neglected "window of opportunities"?}

After the reduction in public social expenditure which took place in most of the countries in the 1980s, there was a significant increase in this expenditure during the 1990s. Thus, between 1990-1991 and 1996-1997 it grew by $38 \%$ for the region as a whole: twice as fast as the per capita product, and exceeding the historical peak levels in three-quarters of the countries. This tendency appears to have continued up to the end of the decade, although we will have to wait for the publication of the EClac Social Panorama of Latin America 2000-2001 for the official figures.
However, full advantage has not been taken of this "window of opportunities", which accompanies the "demographic bonus" 3 enjoyed by the region. It is worth stressing that spending a lot does not necessarily mean spending well, so that one of the pending tasks is to increase the efficiency, efficacy and impact ${ }^{4}$ of such resources: a particularly important consideration in a region where the percentages of GDP devoted to public expenditure are markedly lower than those of the developed countries.

It should also be noted that the margin that governments have for continuing to expand their public social expenditure faster than their economic growth rates is increasingly small. Keeping up the present levels of public resources for social programmes is a current challenge.

\section{Public dissatisfaction}

In the early 1990s, Latin Americans were mainly concerned about the inflationary processes that were eroding their income, and governments that were successful in stabilizing the economy received support at the polls (Mora and Araujo, 1992). Only a few sectors (especially public-sector employees) reacted negatively to their relative losses of income and benefits (ECLAC, 1995). The rest of the population wagered on the future in the hope that they would eventually receive their share of the fruits of growth.

Today, however, uncertainty prevails. The economic and social situation already described has helped to dilute hopes and in many cases has brought to the surface the population's weariness with the ongoing adjustment. Opinion surveys carried out in 16 countries reveal that approximately $67 \%$ of those

\footnotetext{
${ }^{3}$ The expression "demographic bonus" seeks to express the advantage that the Latin American region is enjoying because its population growth rates have slowed and there has therefore been an increase in the proportion of adults within the total population, which should in theory reduce the dependency rate (ECLAC/CELADE, 1996).

${ }^{4}$ Efficiency measures the relation between the cost of a project and the products (goods or services) delivered by it. The objective of efficiency analysis is to find the alternative that minimizes the cost per unit of product. Efficacy reflects the extent to which the production targets of the project have been attained over a given period of time, independently of the costs incurred. The impact, for its part, expresses the size of the benefits received by the target population in line with the objectives of the project: for example, the percentage reduction of grade 1 and 2 malnutrition achieved in the target group by a project having this objective (see Cohen and Franco, 1992).
} 
interviewed consider that the current distribution of wealth is unjust, and $61 \%$ consider that their country is not developing (ECLAC, 1998).

Obviously, those opinions are strongly based on the personal experience of those expressing them. Those who form part of the rising sectors or are emerging from a state of poverty do not feel the same as the members of currently impoverished middle-class sectors, who compare their present standard of living with that which they had in the past.

There are also generational differences. The present generation feel that they have fewer opportunities than the generation which preceded them or that which will follow them (Latinobarómetro, 2000, p. 11).

It is very common for young people to express dissatisfaction at the difficulties they face in finding a job in line with their aspirations. It may be noted that this perception does seem to have a strong basis in fact, especially as regards the evolution of the labour market and the difficulties micro-enterprises and small enterprises experience in operating properly.

There is a notable similarity between the percentage of dissatisfied young people (between 49\% and $63 \%$, according to surveys made in seven countries) and the percentage of persons who have not received an education which ensures them some degree of social mobility through proper integration into the labour market $^{5}$ (between one-third and half). It could be said that these young people with insufficient educational capital become aware at an early age of how predetermined and limited the sequence of opportunities for greater well-being will be for them in the course of their working life (Gerstenfeld, 1998).

In Chile -where the economic reforms have matured more than in other places and high growth rates have been attained- there is growing concern over inequality, which has tended in this respect to take the place of the view of poverty as a lack of resources.
"This change means that the population is paying particular attention to the different rates at which the benefits of economic progress reach different sectors of our society" (Manzi and Catalán, 1998, p. 555). Those interviewed in the lower and middle sectors consider that the current levels of poverty and inequality are not in keeping with the growth achieved. They feel that this inconsistency is due to the dynamics of the system itself and to the policies of the social actors with decision-making power, whom they criticise for their lack of sensitivity. They also call for a more active role on the part of the State (ibid., p. 532).

The perception of inequality and lack of opportunities causes citizens to gradually lose confidence in politicians and institutions and to abandon the political parties (Manzi and Catalán, 1998). They draw away from political activity, which they no longer see as a means for defending their group interests and helping to create a society where social distances are kept down to a reasonable level. They do, however, support democracy as the best system of government, although they do not feel a similar degree of satisfaction with the way it works, because of the high expectations that they had in the capacity of democracy to solve their problems. In fact, only $37 \%$ of Latin Americans are satisfied with the performance of democracy (Latinobarómetro, 2000, p. 6).

It must be acknowledged, however, that any process of development means sparking off various demands. Even when there is economic growth and social progress in the satisfaction of basic needs (drinking water, electricity, rural roads), opinion polls will not necessarily reflect satisfaction. Maslow's theory that the satisfaction of some primary necessities means the immediate appearance of other strongly felt needs (Maslow, 1954) may go some way towards explaining the discontent felt on account of the appearance of new expectations and aspirations.

\footnotetext{
${ }^{5}$ That is to say, an education longer than that of their parents (making allowance for "educational devaluation") which enables them
}

to cross the minimum threshold for proper incorporation into the labour market. 


\section{III}

\section{Emerging social issues}

In a situation like that described above, a fundamental element on the Latin American agenda in the coming decade will be the building of more equalitarian societies, which means incorporating large percentages of the population into the consumer society and creating channels that promote social mobility.

\section{Integration into the consumer society}

In Latin America, most households do not have sufficient income to reach a minimum level of mass consumption. This is a dimension not only of material well-being, but also of status and integration, which are increasingly prized by society. Even so, there are circles which keep on denouncing what they call "consumerism", which they see as a departure from certain cultural patterns, due to the demonstration effect of adopting fashions felt to belong to other social strata and other countries.

In general, only two or three out of every ten urban households currently have a level of per capita income sufficiently high to bring them into the consumer society by Latin American standards. ${ }^{6}$ In rural areas the situation is even more unfavourable. In Uruguay, about half the households qualify for the consumer society, but in the other countries only a third are in this position. According to an optimistic hypothesis, only Argentina and Chile could join the group of Latin American countries with over half their households integrated into the consumer society between now and 2005 (Gerstenfeld, 1998).

It is probably the members of these urban households which are not poor but do not have sufficient income to enter the consumer society fully who are most responsible for the feeling of frustration recorded in surveys (Gerstenfeld, 1998).

\footnotetext{
${ }^{6}$ In order to be integrated into consumer society, a household per capita income greater than three poverty lines is needed. At this point, the distribution displays a clear upward jump in the level of expenditure. It may be recalled that one poverty line naturally represents a situation of poverty, while having an income of up to two poverty lines represents a situation of vulnerability and a risk of suffering poverty at some stage in life.
}

Sustained economic growth is undoubtedly the means by which the broad masses could be integrated into consumer society.

\section{Social mobility}

A modern, open society with a concern for equity should be marked by smooth and easy social mobility. One way of ensuring that the social roles operate correctly is that there should be possibilities and incentives for rising to positions which are better paid or are of higher status. In traditional societies, in contrast, roles are assigned basically through principles of entitlement whereby these positions are reserved by birth.

In the first phases of development there is a kind of "structural" mobility under which new higher-level positions are rapidly created and filled by anyone who has the necessary training for carrying out these functions. In more advanced phases, mobility becomes a "circular" process: not so many new positions are generated, and change must take place through rotation: that is to say, through the departure of some of the occupants of higher positions (by retirement, death or termination) and their replacement by persons with suitable qualifications for the job (Pastore and Silva, 2000, p. 5).

Studies show that only two out of every four urban young people and only one out of every four rural young persons have had educational mobility. It may therefore be concluded that the probability of social mobility has remained practically unchanged since 1980 (ECLAC, 1998). The possibility of changing this pattern is closely linked with the educational system.

It should be noted here that a society based on merit -a "meritocracy"-, in which positions are occupied by those who have certain capabilities, may doom those who do not have those capabilities to exclusion and poverty. This justifies the argument that it is necessary to incorporate an element of solidarity to make up for this lack.

\section{Towards more equalitarian societies}

Great stress is usually laid on the economic aspects of inequality. Latin American experience shows that even in those countries which have managed to comply with 
the recommendation to keep up growth rates of $6 \%$ per year, there is no improvement in income distribution, nor are there any differences with regard to the degree of public satisfaction over what is happening. There is therefore a clear "need to give special attention to economic and social policies which have a direct incidence on aspects of a distributive nature, especially in those areas where there is the greatest sensitivity over inequality (education, housing and health)" (Manzi and Catalán, 1998, p. 555). Likewise, the new intellectual concern with income distribution already referred to has identified relations which appear to show that greater equality in this respect is even preferable for securing higher growth.

While this aspect is very important, it should also be noted that the concern to build more equal societies goes beyond economic matters and material well-being. Other forms of equality, without which a good society cannot exist, are also important.

Such advances in the satisfaction of basic needs entail monetary costs which must be met by the beneficiaries, and this is difficult when there has not been an increase in the productivity of the backward sectors in question and there are no new employment options to support the advances made.

An equalitarian society goes beyond consensus on the most crucial economic elements, however. Firstly, equality is a prior requisite for the proper functioning of the market itself. This is so, for example, in the case of equality before the law, which, although enshrined in the Constitutions of Latin America, is far from prevailing in practice. The reforms being made in systems of justice represent an acknowledgement of the shortcomings which exist in the region in this respect. Another essential requisite is equality of opportunity, understood as the elimination of the disadvantages faced by some persons due to the existence of certain barriers or restrictions or the impossibility of gaining access to certain media. Equality of opportunity means doing away with the connections which exist between the possibilities of well-being and some personal characteristics which it is impossible or extremely difficult to change (sex or race, for example) or which derive from the fact of having been born into a family with certain attributes (socioeconomic level, caste, etc.).

In the final analysis, even when freedom is the main priority it is necessary to ensure that there is equality of freedom, that is to say, to display equal concern, at all levels, for all the persons involved (Sen, 1999, p. 7).

It is also necessary to promote equality of freedom of expression. In any country there are undoubtedly many differing views on how to organize society, and all persons, communities and groups must be guaranteed the right to express their preferences and organize themselves to promote them within the democratic debate.

Many of these principles are of fundamental importance for the proper functioning of democracy. The principle of "one man, one vote" must be respected if democracy is to work. There must be equality of citizenship. Although we talk about the "political marketplace" we cannot permit the (economic) market to determine political decisions. We must ensure that "although people may have different weight and importance in the market as a function of what they own, they must all have the same weight and importance when it is time for them to exercise, as citizens, their civic and political, social and occupational, value-linked and ideological rights" (Hardy, 2000).

Equality of rights as citizens means that differences in personal status do not lead to privileges for some but exclusion for others.

In the field of society and culture, it is also necessary that there should be equality in diversity: that is to say, that individuals, communities and groups of different types should have the possibility of developing their own views of the different dimensions of human behaviour and thus be able to live their differential ways of life, resulting in cultural pluralism.

Growth also depends, however, on social policies insofar as these form the human capital which will be mobilized to permit the proper functioning of the posts needed in order to make the economic system work. Social policies also help to create the political conditions needed in order to give rise to the stability required for investment and the execution of productive projects.

\section{Responsibility of public policies}

Public policies will undoubtedly be one of the key instruments for tackling the social agenda of the end of the century. A good economic policy also has positive social effects. It creates suitable conditions for the generation of employment and good wages, and even when the jobs created are of low productivity and wages, as has mainly been the case in recent years, this allows a larger number of members of poor households to find employment, thus increasing the occupational density of households and hence also their per capita income. Economic growth also facilitates increased public spending, with its potential for improving equity and reducing poverty in the short and long term. 
It should be borne in mind, however, that "the sensitivity of the region's growth to international financial cycles continues to be as marked as ever, despite the growing sophistication of macroeconomic management" (Ocampo, 2000, p. 122). This makes it essential to try to reduce the impact of such cycles on the population in general and its less protected sectors in particular. Moreover, the growing segmentation of the labour market calls for policies designed to prevent relative prices from affecting the hiring of labour; to ensure ongoing training of labour and prepare workers to use new technologies, and to improve labour legislation and establish unemployment insurance schemes which provide workers with protection in periods of recession and of readaptation of production. Since the low-productivity sectors are made up of small and micro-enterprises, which provide employment for over half of all Latin American workers, efforts should be made to promote the introduction of new technology in them, by ensuring that they have access to credit and markets, and to provide them with support in the areas of information, product development, marketing channels and business management.

Policies in the fields of low-cost housing and community facilities are also vital for improving the living conditions of the people, raising the quality of health services and creating a suitable environment for schoolchildren to gain the fullest benefit from education, as well as helping to improve the distribution of wealth. Where the proportion of rural dwellers in the total population is still substantial, it is necessary to facilitate the market access of producers in distant regions by carrying out infrastructural programmes and improving access to land and water.

With regard to social policies, they obviously cannot be responsible for pursuing the objective of equity unaided. Social development is not entirely their exclusive responsibility: this task is shared with economic policy. Social policies have a direct and indirect influence on the reduction of poverty and improvement of living conditions through their three basic functions: investment in human capital, social compensation, and social integration or cohesion.

\section{a) Investment in human capital: education}

When the main production factor is knowledge, there are concrete reasons justifying the pursuit of greater equity, and it is no longer necessary to use only arguments of an ethical, philanthropic or solidarityoriented nature. Countries cannot be competitive if they do not have a properly trained and educated labour force capable of gaining access to technical progress and incorporating it in their everyday work. Competitiveness and equity may therefore be seen as objectives which can be pursued simultaneously and which mutually foster each other. Thus, from the aggregate point of view, social policy oriented towards investment in human capital becomes an essential prerequisite for economic growth. The same is true of the need to train the population in matters of health, so that they can carry out their productive functions properly.

Education is also of key importance for individuals. At the same time, however, it must be acknowledged that this is an inherited asset, especially in the case of high-quality education. Opportunities for well-being are transmitted from one generation to another (ECLAC, 1998), so that there is a link between the household of origin and the number of years of schooling, type of occupation and level of well-being that its new members will be able to attain in the course of their lives.

To begin with, the household of origin has a fundamental role to play in the advantage taken of schooling. There are various features of the household which are of influence in this respect: i) its socioeconomic level; ii) the educational climate prevailing in it, defined as the number of years of schooling possessed by its adult members; iii) the housing conditions (whether there is overcrowding or not), and iv) the form of organization of the family (single-parent or with both parents present; the type of union between the parents is also important).

The future of the new generations is thus defined at an early stage, establishing a big difference between the excluded (those whose education is insufficient to give them a chance of occupying well-paid jobs that will free them from poverty) and the integrated. Those who are in the excluded sectors will not attain adequate levels of living, and they will not be in a position to make a contribution to competitiveness either, because they will lack the knowledge and flexibility needed to incorporate technical progress into their forms of production.

In another link of the chain, educational capital is of key importance in terms of the occupational opportunities young people will have when they enter economically active life, because of two closely interlinked phenomena which must be taken into account in policy design: educational devaluation and the minimum educational threshold level.

Educational devaluation is the loss of importance suffered by certain educational levels as more and more 
people reach them; it reflects the need to complete more and more years of formal education in order to gain access to a given occupation or obtain a similar level of wages to that enjoyed by the preceding generation. ${ }^{7}$ Experience shows that the lower the educational level, the greater the degree of devaluation.

The educational threshold, for its part, is the minimum number of years of education that must be completed at a given time in order to obtain a job which gives a high probability $(90 \%)$ of being able to avoid poverty throughout the rest of one's life. In Latin America, this threshold stands in many cases at the level of 12 years' formal schooling (ECLAC, 1999b) and is only reached by a third of young people in urban areas and one-tenth in rural areas.

Finally, the occupation obtained links up with the opportunities of future well-being, as noted in the Social Panorama of Latin America. Those with less than eight years' schooling will only be able to obtain jobs that provide them with an income around two and a half poverty lines, which is not enough for a minimum level of well-being. At the other extreme, those with 12 or more years' education will be able to work as technicians, managers or owners of businesses, and in these occupations they will obtain incomes over four poverty lines. Those who are in an intermediate position (9-11 years' schooling) will work as salesmen or similar types of work and will receive incomes which at certain stages in their life cycle -when they have formed a family and their children are reaching adolescence-may not be sufficient to give them an adequate level of wellbeing (ECLAC, 1998).

From the point of view of society, the cost of untrained human resources which are not efficient enough for competitive production systems may be defined as: "the growth potential of the human capital endowment which is not realized because of the educational deficits which exist" (Cohen, 1996, p. 4).

Therefore, although educational reform policies which seek to reduce repetition of grades and dropping out and improve the quality of education are very important, they are not of themselves sufficient to overcome lack of equity. It is also necessary to take into account the out-of-school factors that affect educational performance and to make up for differences connected with the household of origin of students, if

\footnotetext{
${ }^{7}$ This question was analysed in depth some years ago by Aldo E. Solari and is dealt with in various ECLAC studies. It has recently been taken up again in the press: see La Tercera (2000).
}

it is desired to prevent the educational system from functioning as a mechanism that reproduces existing differences.

It should be emphasized that the improvement of education is not of itself enough to bring about changes in income distribution in the next ten years. As the rotation of workers in the labour force takes place at the rate of $2 \%$ or $3 \%$ per year, the occupational profile of $80 \%$ of those currently working will continue to apply to the labour market until the end of the next decade. No advantage will therefore be gained from the improvements being made in the educational system, which are designed to affect those who have not yet entered the labour market.

The distribution of access to health is also inequitable, although it must be acknowledged that progress has been made in reducing infant mortality, increasing life expectancy, etc. Nevertheless, there are now new demands which will make it necessary to broaden policies in this field and provide more modern and diversified services, not only in preventive activities. The reform processes carried out so far, in which the private sector plays a significantly greater role than in the past, have given rise to a large-scale debate on the best way of improving efficiency and meeting ever-increasing demands.

\section{b) Social compensation: safety nets}

The struggle to overcome poverty and indigence will continue to be a central issue, and growing importance is being assumed by social safety nets: that is to say, the sets of compensatory measures which increase income and other assets through targeted transfers and are specifically designed to maintain or increase the well-being of poor or vulnerable groups at times of economic transition (Graham, 1994). It is even believed that such measures can increase popular support for the economic transition process, provided there is adequate communication and the participation of those affected is promoted by strengthening their capacity for organization.

Safety nets must be stable, must form part of permanent institutional systems, have specialized staff, suitable mechanisms for determining eligibility, portfolios of projects and established practices for their evaluation, etc. If not, they will be unable to respond in a timely manner to the needs for protection at times of crisis (Cornia, 1999).

Since the 1980s, the protection of the poor at times of crisis has been based on emergency employment 
programmes, anti-poverty programmes and social emergency funds or social investment funds, through which it has been sought to complement the traditional social assistance programmes. It would also be desirable, however, to take measures which keep up employment, such as bringing forward planned investments in infrastructure or promoting public works in communities which have suffered natural disasters or unfavourable economic situations (Iglesias, forthcoming). The basic criterion for such programmes should be to carry them out in a counter-cyclical manner, expanding their coverage and benefits in periods of recession. It would therefore be necessary to identify those branches which should not suffer cuts or should actually be expanded in times of crisis.

\section{c) Social cohesion}

An integrated society is one in which the population behaves in accordance with socially accepted patterns and there is an equilibrium between cultural goals, the structure of opportunities for attaining them, and the formation of individual capabilities for taking advantage of such opportunities. There are of course always types of behaviour which are not in keeping with these patterns and can give rise to increases in social cohesion or, on the contrary, processes of disintegration usually linked with phenomena of exclusion: that is to say, circumstances in which society does not make available to individuals the proper means (opportunities) for attaining the goals imposed by the culture in question (ECLAC, 1997, chapter III, p. 73).

Concern for cohesion does not mean the pursuit of homogenization, since a modern society must respect people's right to their own cultural identity and must

\section{IV}

\section{Conclusions}

On the social level, the situation in Latin America at the end of the twentieth century is not satisfactory. Although economic growth has been restored to some extent, it is not fast enough to improve the levels of living of the whole population. At the same time, while social policies have received very considerable resources, it will not be easy to keep up this social expenditure unless there is sustained economic growth, value diversity, together with the contributions made by the creativity of each cultural group. Thus, while global objectives and rules are shared, there is still room for a wide range of other goals, both of individuals and of groups. This is particularly important in multiracial or multicultural societies.

The traditional problems of low levels of integration displayed by the region (poverty and other problems already referred to, racial discrimination, social segmentation, residential segregation) are now compounded by such new phenomena as various forms of violence, citizen insecurity, drug trafficking and corruption.

This set of situations weakens or destroys the links of shared belongingness, the acceptance of shared patterns of behaviour and the exercise of effective citizenship, while at the same time strengthening exclusive forms of particularism and generating lack of confidence in the public order.

The improvement of social integration is thus also linked to the recomposition of channels of social mobility in keeping with the changes under way, the application of a form of development whose benefits reach all levels of society, a public environment which recognizes and values diversity and promotes the strengthening of the actors of civil society, and a political system in which the demands and interests of all the actors are represented and negotiated.

The incorporation of those who are excluded through various types of discrimination (ethnic, sexbased, etc.) is a task that is still to be completed, in which affirmative action or positive discrimination are fundamental ways of progressing in the struggle to overcome different types of inequality due to family origin, race or sex. ${ }^{8}$ and in any case there will have to be notable improvements in the efficiency of the way such policies

\footnotetext{
${ }^{8}$ For example, by using positive discrimination or affirmative action to reduce differences and inequalities, although this solution is currently being questioned in some circles. Thus, President Fernando Henrique Cardoso has highlighted the resistance that exists in Brazil to a quota system for facilitating the access of negroes to education (see Cardoso, 1998, p. 328).
} 
are applied, in their efficacy in reaching their objectives, and in the impact of the programmes on the beneficiary population.

The future agenda of the region will include the aspiration to build more inclusive and equalitarian societies, with increasing incorporation of hitherto excluded strata of the population into the consumer society and social mobility.

Emphasis must be placed on the importance of democracy and the quality thereof. This is a basic ingredient for a good society. Democracies of the illiterate are not true democracies and very easily open the way to clientism and populism. Societies with large numbers of excluded persons also provide fertile ground for violence and citizen insecurity and end up by affecting the functioning of democracy itself. They lead to a deterioration in the living conditions not only of the poor but also of the integrated sectors, who tend to live in fortified bunkers and to feel insecure when moving around in their own cities, and they encourage the development of the private security industry.

One of the debates which is going on in Europe at present deals with the "two-thirds" society: that is to say, a society in which only two out of every three persons are integrated. In Latin America, however, "one-third" societies currently predominate. The challenge, then, is to create societies in which, as the title of a recent book says, "Everybody's in" (Bustelo and Minujin, 1998). This is the challenge facing the region, which will only be authentically competitive if it simultaneously achieves human development.

As Dahrendorf (1996) says, "Simultaneously achieving growth, cohesion and liberty may be difficult; it may even mean 'squaring the circle', which is of course impossible to achieve in a completely perfect manner, but we can nevertheless come closer to it".

\section{Bibliography}

Berry, A. (1997): The income distribution threat in Latin America, Latin American Research Review, vol. 32, No. 2, Albuquerque, New Mexico, University of New Mexico.

Blair, T. and J. M. Aznar (2000): El crecimiento es el objetivo esencial para Europa, El País, Madrid, 18 June.

Bustelo, E. and A. Minujin (1998): Todos entran, Buenos Aires, United Nations Children's Fund (UNICEF)/ Editorial Losada,

Camdessus, M. (1996): Los nuevos pilares para una nueva solidaridad, Círculo de Montevideo: "Los nuevos caminos de América Latina”, Primera Reunión Plenaria, Montevideo, 5-6 September.

Cardoso, F.H. (1998): El Presidente segundo o sociólogo. Entrevista de Fernando Henrique Cardoso a Roberto Pompeu de Toledo, São Paulo, Companhia das Letras.

Cohen, E. (1996): Presentación, Educación, eficiencia y equidad, Santiago, Chile, Economic Commission for Latin America and the Caribbean (ECLAC)/OAS (Organization of American States)/Ediciones SUR.

Cohen, E. and R. Franco (1992): Evaluación de proyectos sociales, Mexico City, Siglo XXI Editores.

Cornia, A. (1999): Liberalization, Globalization and Income Distribution, Working paper No. 157, Helsinki, World Institute for Development Economics Research, (WIDER).

Dahrendorf, R. (1996): La cuadratura del círculo. Bienestar económico, cohesión social y libertad política, Mexico City, Fondo de Cultura Económica (FCE).

ECLAC/CELADE (Latin American Demographic Centre) (1996): Impacto de las tendencias demográficas sobre los sectores sociales en América Latina: contribución al diseño de políticas y programas, Serie E-CELADE, No. 45, Santiago, Chile.

ECLAC (1995): Social Panorama of Latin America, 1995, LC/G.1886-P, Santiago, Chile.
(1997): The Equity Gap. Latin America, the Caribbean and the Social Summit, LC/G.1954/Rev.1-P, Santiago, Chile.

(1998): Social Panorama of Latin America, 1997, LC/ G.1892-P, Santiago, Chile.

(1999a): The International Financial Crisis: An ECLAC Perspective, LC/G.2040, Santiago, Chile.

(1999b): Social Panorama of Latin America, 1998, LC/G.2050-P, Santiago, Chile.

(2000): Social Panorama of Latin America, 19992000, LC/G.2068-P, Santiago, Chile.

Gerstenfeld, P. (1998): Oportunidades de bienestar y movilidad social en América Latina. Percepciones y realidades, Revista paraguaya de sociología, Año 35, $\mathrm{N}^{\circ} 101$, Asunción, Centro Paraguayo de Estudios Sociológicos (CPES).

Giddens, A. (1998): El centro derecha sigue en la confusión neoliberal, El país, No. 933, Madrid, 22 November.

Graham, C. (1994): Safety Nets, Politics and the Poor, Washington, D.C., The Brookings Institution.

Hardy, C. (2000): Repensar la agenda progresista, Revista Rocinante, Santiago, Chile, October.

Iglesias, E. V. (forthcoming): La crisis, el desempleo y las redes de protección social. Explorando nuevas fronteras, in R. Franco (ed.), Sociología del desarrollo, políticas sociales y democracia, Buenos Aires, Fondo de Cultura Económica (FCE).

ILPES (Latin American and Caribbean Institute for Economic and Social Planning) (1999): Reflexiones sobre el desarrollo y la responsabilidad del Estado, Santiago, Chile.

La Tercera (2000): Santiago, Chile, 24 September.

Latinobarómetro (2000): Informe de prensa, 1999-2000, Santiago, Chile, Corporación Latinobarómetro.

Londoño, J.L. and M. Szekely (1997): Persistent Poverty and Excess Inequality: Latin America, 1970-1995, Working 
paper series, No. 357, Washington, D.C., Inter-American Development Bank (IDB).

Manzi, J. and C. Catalán (1998): Los cambios en la opinión pública, in C. Toloza and E. Lahera (eds.), Chile en los noventa, Santiago, Chile, Office of the President of the Republic /Dolmen Ediciones..

Maslow, H.H. (1954): Motivation and Personality, New York, Harper.

Mora, M. and M. Araujo (1992): Ensayo y error, Buenos Aires, Editorial Sudamericana.

Morley, S. (1998): La pobreza en tiempos de recuperación económica y reforma en América Latina: 1985-1995, in E. Ganuza, L. Tayor and S. Morley (eds.), Política macroeconómica y pobreza en América Latina y el Caribe, Madrid, United Nations Development Programme (UNDP)/Mundiprensa.

Ocampo, J. A. (2000): Nuestra agenda, La CEPAL en sus 50 años. Notas de un seminario conmemorativo, Libros de la CEPAL, No. 54, Santiago, Chile, EClaC.
Ocampo, J.A. (coord.) (2000): Equity, Development and Citizenship, LC/G.2071, Santiago, Chile, ECLAC.

Olasky, M. (2000): Compassionate conservatism, New York, The Free Press.

Pastore, J. and N. do Valle Silva (2000): Mobilidade social no Brasil, São Paulo, Makron Books.

Reich, R. (1993): El trabajo de las naciones. Hacia el capitalismo del siglo XXI, Buenos Aires, Vergara.

Sen, A. K. (1999): Nuevo examen de la desigualdad, Madrid, Alianza Editorial.

Thurow, L. (1992): La guerra del siglo XXI, Buenos Aires, Javier Vergara Editor.

Touraine, A. (1998): 3 y 2 1⁄2, El país, No. 911, Madrid, 31 October.

Wolfenson, J. D. (1998): La otra crisis, address before the Board of Governors of the Federal Reserve System, Washington, D.C., 6 October. 